\title{
What Is Intercultural Sustainability?
}

\section{A First Exploration of Linkages Between Culture and Sustainability in Intercultural Research}

\author{
Dominic Busch ${ }^{1}$ \\ ${ }^{1}$ Universität der Bundeswehr München, Faculty of Human Sciences, Neubiberg, Germany \\ Correspondence: Dominic Busch, Universität der Bundeswehr München, Faculty of Human Sciences, \\ Werner-Heisenberg-Weg 39, 85577 Neubiberg, Germany. Tel: 49-89-6004-3114. E-mail: busch@unibw.de
}

\author{
Received: September 7, 2015 Accepted: November 20, 2015 Online Published: January 26, 2016 \\ doi:10.5539/jsd.v9n1p63 \\ URL: http://dx.doi.org/10.5539/jsd.v9n1p63
}

\begin{abstract}
The sustainability of intercultural relations recently again has been identified as a central, but still neglected responsibility for intercultural research (e.g. Alexander et al., 2014a; Alexander et al., 2014b). This article identifies three different notions of sustainability related to culture in contemporary intercultural research: Egocentric uses focus on one single culture or organization. Utilitarian understandings argue that a sustainable care for intercultural relations may serve other sustainability goals. Allocentric notions ask for a global and equal dialogue on the concept. Complementing the authors above, this article argues for a stronger reflection and analysis of notions of sustainability in intercultural research.
\end{abstract}

Keywords: sustainability, intercultural research, normative orientations, global dialogue, ethnocentrism

\section{Introduction}

Asked about the role and function of intercultural communication research in our contemporary world, several authors in an e-mail discussion published in the Journal of International and Intercultural Communication had claimed that sustainable understanding and peace across cultures are a foremost precondition for a fruitful and enduring development of mankind on a global level (Alexander et al., 2014a). Other authors in this debate warn that many of the contemporary ways of dealing with cultural dynamics is not at all sustainable, yet (Alexander et al., 2014a). And although the provocative hypotheses of Samuel Huntington in the early 1990s at that time soon had been put aside as being too simplistic and ethnocentric, even contemporary authors agree that there is a risk from cultural and interethnic conflict jeopardizing societies' sustainable development (Humphrey, 2013). Summarising this discussion, the authors (Alexander et al., 2014a) recur to Asante and Miike who even earlier had epitomized that "the sustainability of local community, let alone global society, through humanistic connection is the paradigmatic problematique of contemporary intercultural communication scholarship" (Asante \& Miike, 2013). This is supported by Dutta and Dutta (2013) arguing for a culture-centred approach for a responsible and sustainable way of dealing with culture and intercultural communication.

However, these seminal remarks within the academic discipline hardly ever found their way into the wider political discourse on sustainable development. In this article, intercultural sustainability is introduced as a term that comprises any attempt of encouraging durable, long-lasting and resilient forms of intercultural communication and intercultural relations. Consequently, sustainability of intercultural communication and intercultural relations here are seen as an essential dimension of the discourse on global sustainability that comprises numerous dimensions from different fields of social activity. The notion of intercultural sustainability can help to sharpen researchers' consciousness for the responsibility and for the inevitable (social) normativity of their works without anticipating or prescribing the ways to reach these given goals - as debates on intercultural competence have tried to, frequently (for a very short summary c.f. Spitzberg \& Changnon, 2009).

This article is out to encourage a future debate on the potential as well as on the pitfalls of the notion of intercultural sustainability by providing a rapid appraisal of to-date uses of the term sustainability in connection with aspects of intercultural communication and intercultural relations. This first overview is on the one hand open to any understanding of the terms under research in the fields of culture and sustainability. On the other 
hand it seeks out to identify and to explore potential systematics and categorizations to describe potential linkages between culture and sustainability in research.

\section{Sustainability Seen from the Social Sciences}

As a very first sketch on the innovative topic of intercultural sustainability, this article will thus choose a textual approach checking in what ways the literal words sustainable and sustainability are used when related to culture. This approach surely has its strong limitations, and interpretive analyses will need to follow if intercultural sustainability may really be considered as a scholarly concept in future studies. To keep track of these present limitations for the time being, a few notes on the previous sustainability discourse as well as on hidden normative orientations underlying social research will precede the announced survey.

Parallel to the affirmative discourse on sustainability in organizational and management research, the social sciences shelter some critical and descriptive works on what is being done within sustainability discourse (for a complaint about the scarce contribution from cultural anthropology c.f. Singer, 2011). Discourse analysts in particular, emphasize that the notion of sustainability is by no means as unanimous and as goal-oriented as discourse may pretend. Instead, notions of the phenomenon are highly changeable and context-sensitive. However, large parts of contemporary discourse recur to a small number of initial documents. Accordingly, many authors (here e.g. Throsby, 2008) trace the hype on sustainability back to the 1972s statement by the Club of Rome on "The Limits to Growth" (Meadows et al., 1972). Subsequently, authors (here e.g. Axelsson et al., 2013) point at 1987's Brundtland Report published by the United Nations' World Commission on Environment and Development (WCED) (WCED, 1987). The 1992 UN Earth Summit in Rio de Janeiro is often seen as another important step in the development of the sustainability paradigm (Duxbury \& Gillette, 2007). Here, some first steps on how to approach sustainability on a global level had been substantiated (UN Department of Economic and Social Affairs, 2006). The sociocultural dimension of the sustainability discourse can be seen as the result of a series of conventions including "the Mondiacult conferences in Mexico City (1982), Stockholm (1998), and the Universal Declaration on Cultural Diversity (UNESCO, 2001)" (Moosmüller \& Schönhuth, 2009).

Today, the many facets of the notion of sustainability are said to lay the ground for its "constructive ambiguity" (Robinson, 2004). Beyond this, the constructivist nature of the sustainability movement may comprise some hidden dimensions. German philosopher Siegfried Timpf (2003) analyses the sustainability movement in the lights of Foucault's dispositive theory (cf. "dispositions", Foucault, 1984 [1969]). According to Timpf, the idea of sustainability suggests that the narrowness of ecological resources is something that can be successfully managed. This treatment by management has become an option after that discourse had replaced the notion of nature (which is not manageable in the end) by the notion of environment (which does not have any point of origin and which therefore can be managed). Sustainability from this perspective allows a rhetoric according to which mankind has the chance to fully keep control over its future. Considering the use of the sustainability paradigm in intercultural research it may thus be asked to what extent its use here too may bring along the risk of trivializing the issue at hand.

\section{Method: A Literature Review}

Since the question of interrelations between intercultural research and sustainability discourse is a recent and pioneering issue, this article will lay a first ground by means of a review of the existing literature that can be fruitful to this undertaking. For the same reason, and to present an overview that is as all-embracing as possible, several different approaches have been chosen to identify relevant works:

Firstly, a general Internet search on academic work on sustainability and culture has been carried out. Secondly, a more in-depth search confined to academic and up-to-date publications in intercultural communication has been added. Finally, the most relevant international academic journals that explicitly relate to intercultural research in their titles have been analysed in more detail. Here, the full text online archives of the selected journals have been searched for the words sustainable and sustainability. Articles from the hit list have been omitted when the search items did not appear but in the article's references or when the word sustainable had not been made use of but as an adjective in a general meaning outside the focus of the research at hand. Similarly, mentions have been left out if they relate to development fields other than culture without taking into account culture as any form of contribution to this goal. Also, mentions of the term within book reviews have been omitted. This search has distilled the following titles:

The Journal of International and Intercultural Communication (JIIC) of the (U.S. based) National Communication Association is published with Taylor and Francis. Its online full text archive dates back to its first issue in January 2008. Here, eleven articles have been identified as relevant (Alexander et al., 2014a; Alexander et al., 2014b; Anguiano et al., 2012; Broome \& Collier, 2012; Collier, 2009; Dutta \& Dutta, 2013; 
Fraser et al., 2011; Herakova, 2009; LaFever, 2008; Ojwang, 2008; Sekimoto, 2012).

The Journal of Intercultural Studies (JIS) is maintained by the Centre for Citizenship and Globalisation at Deakin University, Australia, and it is also published with Taylor and Francis. Its online archive dates back to the journal's first volume published in 1980, and here, 21 articles have been selected (Ambrosini \& Boccagni, 2015; Boese \& Phillips, 2011; Busbridge \& Winarnita 2015; Castles, 2013; Catney et al., 2011; Collins, 2013; Dahinden et al., 2014; Dawe, 2007; Downman, 2012; Gvion, 2014; Humphrey, 2013; Jakubowicz, 2011; Kesten et al., 2011; Khan, 2014; Kubal, 2013; Mansouri \& Pietsch, 2011; Mondain \& Diagne, 2013; Muñoz, 2011; Poucki \& Bryan, 2014; Poynting \& Mason, 2006; Stolle-McAllister, 2013).

The Journal Language and Intercultural Communication (LAIC) held by the International Association of Languages and Intercultural Communication (IALIC) and published with Taylor and Francis has been searched in its online full text archive from 2001 until September 2014. Six articles have been identified here (Bartlett, 2004; Stibbe, 2004; Gu, 2010; Tange, 2010; Henderson, 2011; Briel, 2013).

The International Journal of Intercultural Relations (IJIR) is the journal of the International Academy for Intercultural Research (IAIR) and it is published with Elsevier. A search in its online archive from 1977 until September 2014 has identified 15 relevant articles, here (Cushner, 2005; Woods et al., 2011; Davidheiser, 2005; Kealey et al., 2005; Kelman, 2005; Marsella, 2005; Salzman, 2008; Cvajner \& Sciortino, 2010; Buddenhagen \& Baldwin, 2011; Nijhuis et al., 2011; Rivers, 2011; Dunne, 2013; Rienties \& Nolan 2013; Kuchenbrandt et al., 2014).

The Journal of Intercultural Communication Research (JICR) is the journal of the World Communication Association and it is published with Taylor and Francis. JICR's online archive has been searched from its beginning in 2006. Here, five articles have been identified as relevant to analysis (Pearson et al., 2010; Tamam, 2010; Hoover, 2011; Takahashi \& Meisner, 2011; Johnson \& Callahan, 2013).

The web-based Journal of Intercultural Communication (JIC) (www.immi.se) has an archive dating back until 1999. A similar search has been carried out here identifying two articles (Stier, 2006; Wei, 2009).

Interculture Journal (IJ) is another web-based (www.interculture-journal.com) journal on the issue. Its articles are published partly in German language, partly in English. In this case, the German language equivalents to the English search items have been included into the search taking the adjective nachhaltig [sustainable] and the noun Nachhaltigkeit [sustainability]. Ten articles have been found here (Nazarkiewicz, 2003; Rathje, 2003, 2006; Strewe, 2007; Hennecke, 2008; Scheible, 2009; Kriegel, 2010; Bolten, 2011; da Silva \& Drawert, 2011; Waibel, 2012).

\section{Results: Egocentric, Utilitarian and Allocentric Understandings of Culture and Sustainability}

Considering culture, intercultural communication and intercultural relations, authors in this field present diverging visions on how these phenomena may be managed to best contribute to global peace, to constructive living together and to a general sustainable development of societies. Focusing on the question of how sustainability goals are supposed to be reached, the literature review suggests a systematics distinguishing between egocentric approaches focusing one side of participants in intercultural contact in particular vs allocentric approaches striving for an equal consideration of all sides in a dialogic manner. Furthermore, utilitarian uses of cultural and intercultural sustainability will be identified in literature seeing intercultural understanding as a tool to support the sustainability of other social dimensions.

\subsection{Egocentric Uses of the Sustainability Paradigm}

\subsubsection{Pleas against Sustainability}

There are almost no clear pleas against sustainability aims. However, some authors mention that striving for sustainability may impede the accomplishment of competing goals. Briel (2013) (LAIC) for example cites a complaint according to which strives for ecological sustainability slows down the use of mass media for building a stronger civil society. Kealey et al. (2005) (IJIR) report on a development project that could not be continued in a sustainable way because competing issues of environmental protection had been ignored. Conversely, Collins (2013) (JIS) critically reports that some speakers in Australia are concerned about increased immigration as a challenge to the country's ecological sustainability.

\subsubsection{Ethnocentric Notions of Culture Do Persist}

Even within cultural research, ancient notions of culture impeding intercultural dialogue still persist in some fields. Sekimoto (2012) (JIIC) as well as Dahinden et al. (2014) (JIS) here remind us that not only cultures but also understandings of culture can be seen as ideologies that perpetuate themselves. Social and mass media 
discourse reinforce the persistence of essentialist and static notions of culture that originally had been developed by research and that may impede intercultural relations and constructive dialogue and exchange (Rathje, 2003) (IJ).

\subsubsection{Supporting the Persistence of Cultures (and Thus Diversity)}

Cultural identity and cultural diversity are by many authors seen as valuable goods worth of being sustained. First of all, cultures have their internal mechanisms ensuring their sustainability, per se. Mondain and Diagne (2013) (JIS) show that even those parts of migratory societies that stay at home may develop a strong sustainability since they have transformed into parts of a transnational (migratory) network. However, certain conditions also may threaten the sustainability of cultural groups (Mondain \& Diagne, 2013), and thus, Austrian philosophers Heintel and Krainer (2010) focus on ways to encourage the creative force of cultures. If culture can produce cohesion for a given community, people should develop strategies for a systematic seizure of these positive effects. Thus, Heintel and Krainer argue for a controlled process of becoming aware of one's cultural visions. Especially in contexts of strong asymmetries of power, the sustainable preservation of identities of minority groups may turn out to be a desirable issue, as can be seen with the Roma in Eastern Europe (Herakova, 2009) (JIIC) or with tribal communities in Northern Thailand (Downman, 2012) (JIS). At the example of the Aboriginal Peoples in British Columbia, LaFever, (2008) (JIIC) adds that minorities' sustainability may also be strengthened by means of stable relationships with the majority group. On the basis of an empirical study, Johnson and Callahan (2013) (JICR) outline the far-reaching impact of social media for the empowerment of cultural minorities. Ploner (2009) (LAIC) adds that a promotion of regional tourism can sustainably foster regional cultural identities. Gvion (2014) (JIC) specifies that even forms of constructed authenticity in the display of cultural heritage may help to foster identities. From a more critical perspective, Dawe (2007) (JIS) warns that the development of a region's touristic attractiveness will require a lot of caution if sustainable regional development is aspired.

Cultural planners confirm the value of cultural diversity in its own right. Duxbury and Gillette (2007) promote culture as an important pillar in the range of sustainability goals. In the example of Sweden, Axelsson et al. (2013) even propose quantitative methods to measure a region's cultural sustainability. In another vein, Pearson et al. (2010) (JICR) reveal that a strong family communication cohesion will strengthen ethnic and cultural affiliation. Both attitudes will contribute to sustainable community building and civil society. Conversely, from this perspective, ethnic diversity can be seen as a threat to cultural sustainability. Catney et al. (2011) (JIS) criticise this view that is often promoted by politically conservative discourse. Instead, they say that there is no immediate interrelation between homogeneity vs. diversity and sustainability. In contrast to this, Fraser et al. (2011) (JIIC) see a real challenge in the unequal distribution of international support for (economic and ecological) sustainable development. Minority groups and societies from developing countries continue to be disadvantaged in this (allegedly) global movement.

\subsection{Utilitarian Uses: Organizational and Corporate Success}

Cultural sustainability efforts may serve both cultural community-building as well as economic growth. However, some approaches still narrow their focus on cultural sustainability as being a tool for economic growth at first place. Kealey et al. (2005) (IJIR) for example report on the egoistic orientation of many organizations, even those in the development sector. Throsby (2008) contrasts that so far, only ecological sustainability has been acknowledged as a key condition for long-term economic growth and success. Cultural sustainability, according to him, has a similar impact but people's awareness of these effects will still need to be raised. For the level of local communities, Muñoz (2011) (JIS) points out that a care for people's religious identities may strengthen a community's general social sustainability and cohesion. Anguiano et al. (2012) (JIIC) report that in some cases, the distribution of ecological and environmental resources is tied to ethnic or racial belonging. This is illustrated at the example of Latino communities in the U.S. where a sustainable intercultural dialogue may help to implement a more just and equal distribution of environmental resources.

A strong corporate culture may support a corporation's internal conflict management capacities. According to Kriegel (2010) (IJ), internal conflict is one major obstacle to sustainable economic success. Conflict may be even more challenging in international settings, and Rathje (2006) (IJ) adds that consequently, organizational cultures should be sustainably taken care of since they are a core part of employees' identities. Intercultural training may be of help here, and even more, it may be an indirect supporter of economic growth. Scheible (2009) (IJ) states that intercultural training may sustainably improve the employees' intercultural competence, and this again may support economic sustainability. Wei (2009) (JIC) supports this view for the transnational level of entire nations. Accordingly, countries will always be interested in the maintenance and the growth of sustainable 
communicative relations with other countries to ensure their economic growth. Even more, Castles (2013) (JIS) reminds us of the fact that permanent immigration (of people from other ethnic cultures) is a precondition for sustainable economic growth in most of the first world countries.

Technological advance is another major field besides from economic growth that receives attention in sustainability discourse. Again, cultural sustainability may be added to support this aim. While De Beukelaer and Duxbury (2014) present practical examples from cultural planning projects in Canada, Hawkes (2001), Khan (2014) (JIS) as well as Mansouri and Pietsch (2011) (JIS) do so for Australia. These thoughts become even more crucial considering the general insight that any technological advance is based on culture-specific assumptions and visions. This general impact of culture on sustainability goals even has been acknowledged by the United Nations: Ban Ki-moon, its Secretary General, has summed up in June 2013 that when the UN had formulated their Millennium Development Goals (MDG) for the period from 2000 to 2015, they had neglected the central role of culture for the pursuit of sustainable development goals (Ban Ki-moon, 2013). Since then, the General Assembly has published two resolutions on culture and development in 2010 and 2011. In 2013, another UN conference took place in Hangzhou on "Culture: A Key to Sustainable Development" (Ban Ki-moon, 2013). Here again, culture still seems to be understood as an add-on that may support sustainability goals in other fields. If the role of culture for general sustainable development is that decisive, a culture of sustainability therefore may be the most precise solution, say Parodi et al. (2011) in their edited volume.

\subsection{Allocentric Uses of the Sustainability Paradigm}

Allocentric notions of the sustainability paradigm will consider all cultures as equal and as equally valuable. Cultures here should be preserved to ensure a sustainable cultural diversity as well as a sustainable peaceful living together across cultures.

A number of mentions in literature point at the importance of peaceful intercultural coexistence for general global sustainability aims. This concern is supported for example by Oetzel in the discussion summed up by Alexander et al. (2014b) as well as by Yin in the same discussion (both JIIC). Additional exemplary mentions can be found in Dutta and Dutta (2013) (JIIC) as well as in Busbridge and Winarnita (2015) (JIS). Conversely, Humphrey (2013) warns that intercultural conflict may endanger sustainable development. Consequently, Marsella (2005) (IJIR) argues for designing cultures themselves in ways that encourage intercultural understanding and peace. Jakubowicz (2011) (JIS) defines multiculturalism as an approach in cultural policy that tries to reconcile egocentric and allocentric understandings of sustainability. Accordingly, sustainable multicultural societies build upon cultural organizations and institutions that strengthen these particular cultural identities and that at the same time initiate contact with neighboring groups. Similarly, Kubal (2013) (JIS) recommends that a country's local law should be designed in a way that it is compatible with the understandings of law and justice of local migrant groups to ensure a sustainable livelihood in place. Canada and Australia in particular here are known for their early efforts of establishing sustainable local communities by introducing concepts like multiculturalism the actual specifications of which are under permanent discussion since then (Mansouri \& Pietsch, 2011; Poynting \& Mason, 2006) (both JIS). Bolten (2011) (IJ) instead specifies that sustainable intercultural relations will need to base upon reciprocal interpersonal relations, and Morris (2010) adds that an understanding of cultures based on boundary-making and on mutual evaluations will impede the implementation of sustainable societies. What is needed instead is a widespread promotion of non-exclusive and non-judgemental notions of culture.

Sustainable intercultural relations will not emerge by themselves, Stier (2006) (JIC) argues. Instead, societies will need to deliberately avow themselves to sustainability goals (Mendoza, 2010). Ambrosini and Boccagni (2015) as well as Boese and Phillips (2011) (both JIC) point out that the local community level may be the most immediate entry point for ensuring intercultural sustainability.

Besides from these general concepts, education may be seen as the field of application in which the notion of sustainability plays the most prominent role. Here, many authors agree that sustainable intercultural relations are ensured best the more people deeply internalize this goal in their worldviews. Specifying this aim, Woods et al. (2011) (IJIR) recommend that university students should be taught to become global citizens. Similarly, Crosbie (2014) (LAIC) argues that sustainable democracy as well as sustainable living together on a global level cannot be reached but through global citizenship which is based on cosmopolitan attitudes. Regarding education as a process, Tran (2009) (LAIC) reminds us of the fact that learning processes are largely based on individual and subjective constructions and re-constructions and that concepts for sustainable intercultural relations should be grounded here.

Foreign language teaching may be seen as a special field in education that seems even more suitable for the 
promotion of allocentric ideas of sustainable intercultural relations (Rivers, 2011) (IJIR). Especially in the field of higher education, there is still a large potential that is unused, say Coperías Aguilar (2009) and Saraceni (2009) (both LAIC).

\subsubsection{Plurality of Languages Instead of Hegemony of English}

Considering the role of languages, authors have different visions on how to ensure sustainability for a global living together and intercultural relations. Gu (2010) (LAIC) for example argues in favour of a stronger promotion of English in China. Internationalization here is seen as a way to sustainably consolidate international relations. Other authors, like for example Tsuda (2010) see the spread of English and the corresponding internationalization processes as results of a Western ethnocentric worldview neglecting cultural diversity. In practice, Ojwang (2008) (JIIC) says that linguistic diversity in Africa contributes to societies' general sustainable development since neighboring languages very often can be mutually understood by their speakers. This closeness may result in a much stronger common identity than the enforcement of an external language as a lingua franca. The same argument is supported for intercultural exchanges by means of artistic literature (Adejunmobi, 2008) (LAIC).

Guilherme (2007) (LAIC) suggests a compromise for a sustainable seizure of global English, which should not be seen as a lingua franca but as an international language. Doing so, Guilherme wants to promote a cosmopolitan attitude: English may be promoted as long as it helps and enriches international communication. In parallel, linguistic diversity is supposed to be preserved to avoid ethnocentrism (e.g. Bruen 2005).

\subsubsection{Student Exchange Research}

International student exchange projects have become the sine qua non tool for the promotion of international understanding over the last decades. On the basis of these numerous individual encounters, sustainable peace and positive intercultural relations are supposed to be ensured on the macro-level of societies.

However, exchange research raises the question of the sustainability of attitude changes from short-term exchanges. While reliable solutions to this question are hard to find, numerous authors confirm the aim of sustainability (e.g. Kuchenbrandt et al., 2014) (IJIR). Rienties and Nolan (2013) (IJIR) as well as Dunne (2013) (IJIR) specify that interpersonal friendships from exchange programs should be made sustainable. In contrast to this, for da Silva and Drawert (2011) (IJ) students' mobility is the core aspect that should be made more sustainable. Henderson (2011) (LAIC) clarifies that participants of exchange programs should consciously understand that their attitude changes and their new friendships should be sustainable. Waibel (2012) (IJ) and Furcsa (2009) (LAIC) add that intercultural contacts and individual intercultural friendships can also be tied via virtual networks.

\subsubsection{Internationalization at Home}

Intercultural contact can even be experienced at people's local workplaces as well as in their everyday surroundings, since international and intercultural mobility and migration are omnipresent in today's globalized world. However, this potential very often remains unused or it is not used in a systematic way, as Tange (2010) (LAIC) criticizes. For the example of school teachers, Tange thus argues for the implementation of a "sustainable teaching practice", i.e. that teachers in the first place will need to be enabled to provide their classes in English language.

\subsubsection{Intercultural Training}

Although intercultural training in its traditional form is normally seen as an educational measure that is used in corporations and professional organizations (for sustainability as a training goal see Kealey et al., 2005), its effects do not necessarily have to be confined to institutional benefits. Trainees will also profit from intercultural trainings on an individual basis and they will thus be able to better contribute to the establishment of sustainable intercultural relations in general (Cushner, 2005). Nazarkiewicz (2003) (IJ) reminds us that culture in general can be seen as a tool for social orientation of individuals. Intercultural training may thus influence the core components of individuals' orientations, and intercultural training can contribute to forms of behaviour that support sustainable intercultural relations. However, it cannot be taken for granted that any intercultural training will have sustainable effects (Collier, 2009) (JIIC). Thus, similar to research on international exchanges, research on intercultural trainings has one central question: How can intercultural trainings be designed in a way that the training has long-term effects, i.e. that its effects are sustainable (Strewe, 2007; Bolten, 2008)?

\subsubsection{Cultural Planning on a Community Level}

The sustainability of the livelihood of local communities with people of diverse cultural identities can become an 
issue of systematic cultural planning (e.g. Kesten et al., 2011) (JIS), and Stolle-McAllister (2013) (JIS) emphasize that this form of sustainability should be ensured equally for any groups at any place. Khan (2014) (JIS) analyses policy documents on cultural planning in Australian suburbs. Interestingly, she does not find any mention of culture as a term here. Instead texts on cultural planning tend to speak about sustainability in general. However, from the context, Khan interprets that what is actually meant by sustainability here can be specified as cultural participation. So in this case, Khan reveals that intercultural sustainability is frequently seen as the core dimension of sustainability on a community level in general. Poucki and Bryan (2014) confirm the urgent need for measures to ensure sustainable livelihoods on a community level since otherwise, even serious threats as for example human trafficking may emerge across cultural boundaries.

\subsubsection{Politics and International Conflict Management}

Political action, and the field of diplomacy in particular, may aim at the establishment of sustainable intercultural relations, but they will normally pursue egocentric goals even if they may be announced as allocentric in public. However, it is generally hard to verify whether intercultural relations are considered as an aspect of sustainable living together or whether they are seen as a basis for hegemonic claims.

International conflict studies from a political science perspective generally seek for ways of sustainable peace-building (Kelman, 1998, 2005). Here, Broome and Collier (2012) (JIIC) argue for a stronger and a more explicit commitment of intercultural communication scholars in efforts on sustainable intercultural peace-building. Davidheiser (2005) (IJIR) presents ethnographic data from The Gambia showing that in this case, sustainability is considered as one of the primary criteria for good conflict resolution and that it is shared as a goal even beyond Western cultures. Salzman (2008) (IJIR) turns our attention to the challenge of religious conflicts and religious fundamentalism. These lines of conflict on an international level very often are seen as more or less intractable and hard to mediate. In these cases, Salzman assumes that sustainable solutions cannot be reached but if people manage to coordinate their actual needs instead of insisting on their fundamentalist attitudes.

\subsubsection{Development Aid}

In a similar vein, sustainability is one of the major goals in the field of development aid: The effects of development projects are supposed to persist and to continue after a project has been closed. Nijhuis et al. (2011) (IJIR) confirm this goal in the example of aid projects in the field of educational curriculum development in Ghana. Buddenhagen and Baldwin (2011) show in the example of development projects in Tanzania that even the project workers themselves have internalized sustainability as a primary aim of their work.

Hennecke (2008) (IJ) points out that people from different cultures have different approaches to the use of technologies. If cultural particularities are neglected, even technological developmental aid will lack sustainability. Also, the subfield of development communication promotes the aim of sustainability. Cvajner and Sciortino (2010) (IJIR) in the example of Kenya present a cultural learning approach to the sustainable management of social problems and social conflict.

\section{Discussion}

The literature survey on the use of the notion of sustainability in recent publications on intercultural research has shown that the mentions found can best be divided into three major functional categories. Egocentric approaches aim at a promotion of the sustainability of one single culture or organization. Normally, this is the culture or the organization the authors themselves belong to. Utilitarian approaches argue for a sustainable care towards culture and cultural relations for the sake of a goal that is outside the thematic field of intercultural communication or intercultural relations. In most cases, intercultural sustainability here is seen as a tool to strengthen the sustainability of economic or political success of a corporation, an organization or even a nation. Finally, allocentric approaches see the sustainability of intercultural relations and peaceful and constructive cohabitation as a core value that has to be encouraged. Central to this notion is a dialogical approach including all sides concerned into the intercultural interaction process in an equal and egalitarian way. Peaceful and constructive intercultural relations all over the world can be seen as a very basic pre-condition for the sustainable development of any other social fields. If peaceful development is interrupted by conflict on a global scale, economic, political and ecological sustainable development can experience serious setbacks.

However, this literature review confirms some of the fears raised by Alexander et al. (2014a) that had been taken as its starting point: Allocentric concepts of intercultural sustainability are needed, but in many fields of action, they are not much more but a vision, so far. They can be found in a few fields of education and cultural planning at a community level, at best. In other fields like for example business management, allocentric notions of 
intercultural sustainability are hard to find.

\section{Limitations and Questions for Future Research}

The results of this article confirm the call of Alexander et al. (2014a) for a more conscious and responsible research on intercultural communication and intercultural relations considering sustainability needs and goals in this field. The distinction between egocentric, utilitarian, and allocentric understandings of intercultural sustainability here may help to focus on the precise effects of the underlying goals of studies at hand. Although intercultural sustainability may be agreed upon as a desirable goal for intercultural research, some more pitfalls may need to be researched and taken care of:

Concepts of intercultural sustainability run the risk of being essentialised (for an example e.g. Vachon, 2010) and - as a consequence - as being formulated from one single culture-specific perspective. Stibbe (2004) (LAIC) has revealed this dilemma at the example of environmental sustainability. To ensure an allocentric and dialogic orientation in intercultural sustainability research, its concepts will need to be open to permanent discussion and re-negotiation (e.g. Bartlett, 2004) (LAIC), and they will permanently need to be brought back into researchers' consciousness by means of analyses and descriptions (e.g. Takahashi \& Meisner, 2011) (JICR). Here, Hoover (2011) (JICR) warns that even notions of dialogue tend to be culture-specific. Even more, reflecting upon the sustainability of a given action thus will always be led by a moral judgement: Those actions that are assumed to be sustainable are good, other actions are bad. Since notions of sustainability can be culture-specific and since they are products of social discourse, these moral judgements may be deliberate to some degree. The question of whether the behaviour of a given group, a culture, or an individual is sustainable or not, can thus be used as an argument and as an instrument in conflict discourse.

A critical observation of intercultural research considering sustainability may also raise the question of whether culture-essentialist approaches in general will always impede allocentric sustainability goals since they cannot but re-confirm the incommensurability of cultures as Holliday (2010) and Dervin (2014) (LAIC) criticise. Furthermore, future research may attempt to specify more clearly, what sustainable intercultural relations may look like. This may be done by firstly tracing dialogue and negotiations on this actual question, but also for example by descriptions and evaluations of best practice scenarios. Furthermore, the notion of intercultural sustainability will need to be sharpened in its relations to neighbouring concepts: In what way does intercultural sustainability exceed the existing concepts of intercultural dialogue, and in what aspects does it differ from existing concepts of intercultural competence? The potential of intercultural sustainability in contrast to intercultural competence may bee searched for in its radical basical openness refraining from the temptation of promoting solutions at a too early and too general stage.

\section{Conclusion}

This article has analysed the use and the potential of the notion of intercultural sustainability for the research field of intercultural communication. The analysis has been based on three assumptions: On the one hand, some authors (e.g. Alexander et al., 2014a; Alexander et al., 2014b) warn that sustainable intercultural understanding will be a pre-condition for a general and global sustainable development of societies. From this, there is a growing responsibility on intercultural research to consciously analyse and focus on this potential which currently is neglected by societies as well as by academia. On the other hand, the notion of sustainability is considered by quite a number of academic works in the field, already. However, sustainability in most cases lacks further specification. Third, although sustainability aims can be derived from research on intercultural communication, this thematic field is not included in the official dimensions of sustainability discourse, yet.

On the basis of a first and exploratory literature review, this article has suggested a distinction of three different notions of the interrelation between culture and sustainability. Egocentric uses of the sustainability paradigm are based on a one-sided perspective on intercultural relations. According to traditional notions of intercultural competence, these approaches reflect upon the potential of creating sustainable intercultural relations from the view of one single actor. These approaches normally are based upon ethnocentric assumptions on cultural and intercultural theory. This category includes approaches that are simply ethnocentric, but also those approaches that are written from the perspective of or in favour of a single organization, corporation, group or person.

Utilitarian uses of the sustainability paradigm see culture and competent ways of managing cultural diversity as an instrument to support the achievement of sustainability goals in other sectors of social action. For example, many approaches see cultural sustainability as a necessary contribution to economic and/or corporate success. Sustainable positive intercultural relations are not ascribed a value of themselves, though. In theory, utilitarian approaches can be based upon egocentric as well as upon allocentric understandings of sustainability. 
Allocentric uses of the sustainability paradigm acknowledge the necessity of having all sides concerned participate in a mutual dialogue on what intercultural sustainability is and how it can be reached. As a consequence, these approaches do not suggest definitions of or roadmaps for intercultural sustainability. Instead, they argue for the salience of the idea and they promote forums to initiate intercultural dialogue on intercultural sustainability. Currently, these approaches primarily can be found in research on education, esp. foreign language education, as well as cultural planning on a community level, foreign aid and politics.

Besides from this categorization, this article has revealed a number of pitfalls arising from reflections on intercultural sustainability. One major concern lies in the permanent risk of essentialising the notions of the term. Concepts from discourse theory may show that large parts of social research are more or less bound to society's normative orientation irrespective of a work's descriptive or analytical character.

Research on intercultural communication and intercultural relations has the chance of becoming much more transparent as well as efficient when its normative goals as well as its potential orientations towards intercultural sustainability will be discussed and reflected in an open forum. Even more, research on intercultural communication can make a significant and necessary contribution to the global discourse on sustainability and sustainable development.

\section{References}

Adejunmobi, M. (2008). Intercultural and transcultural literacy in contemporary Africa. Language and Intercultural Communication, 8(2), 72-90, http://dx.doi.org/10.1080/14708470802270828

Alexander, B. K., Arasaratnam, L. A., Durham, A., Flores, L., Leeds-Hurwitz, W., Mendoza, S. L., et al. (2014a). Identifying key intercultural urgencies, issues, and challenges in today's world: Connecting our scholarship to dynamic contexts and historical moments. Journal of International and Intercultural Communication, 7(1), 38-67, http://dx.doi.org/10.1080/17513057.2014.869527

Alexander, B. K., Arasaratnam, L. A., Flores, L., Leeds-Hurwitz, W., Mendoza, S. L., Oetzel, J., et al. (2014b). Our role as intercultural scholars, practitioners, activists, and teachers in addressing these key Intercultural urgencies, issues, and challenges. Journal of International and Intercultural Communication, 7(1), 68-99, http://dx.doi.org/10.1080/17513057.2014.869526

Ambrosini, M., \& Boccagni, P. (2015). Urban multiculturalism beyond the 'Backlash': New discourses and different practices in immigrant policies across European cities. Journal of Intercultural Studies, 36(1), 35-53, http://dx.doi.org/10.1080/07256868.2014.990362

Anguiano, C., Milstein, T., De Larkin, I., Chen, Y.-W., \& Sandoval, J. (2012). Connecting community voices: Using a Latino/a critical race theory lens on environmental justice advocacy. Journal of International and Intercultural Communication, 5(2), 124-143, http://dx.doi.org/10.1080/17513057.2012.661445

Asante, M. K., \& Miike, Y. (2013). Paradigmatic issues in intercultural communication studies: An Afrocentric-Asiacentric dialogue. China Media Research, 9(3), 1-19.

Axelsson, R., Angelstam, P., Degerman, E., Teitelbaum, S., Andersson, K., Elbakidze, M., et al. (2013). Social and cultural sustainability: Criteria, indicators, verifier variables for measurement and maps for

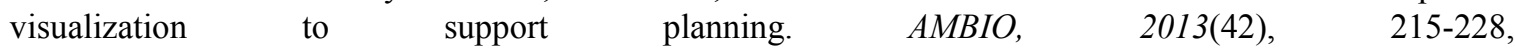
http://dx.doi.org/10.1007/s13280-012-0376-0

Ban Ki-moon (2013). Secretary-General's remarks at General Assembly thematic debate on culture and sustainable development. New York: Statement at General Assembly of United Nations, 12 June 2013.

Bartlett, T. (2004). Genres of the third space: The communities strike back. Language and Intercultural Communication, 4(3), 134-158, http://dx.doi.org/10.1080/14708470408668869

Boese, M., \& Phillips, M. (2011). Multiculturalism and social inclusion in Australia. Journal of Intercultural Studies, 32(2), 189-197, http://dx.doi.org/10.1080/07256868.2011.547176

Bolten, J. (2008). Reziprozität - Vertrauen - Interkultur. Kohäsionsorientierte Teamentwicklung in virtualisierten multikulturellen Arbeitsumgebungen [Reciprocity - trust - interculture. Cohesion-centered team-building in virtual multicultural workplaces]. In E. Jammal (Ed.), Vertrauen im interkulturellen Kontext [Trust in intercultural contexts] (pp. 69-93). Wiesbaden: VS-Verlag.

Bolten, J. (2011). Diversity Management als interkulturelle Prozessmoderation [Diversity management as moderating intercultural processes]. Interculture Journal, 10(13), 25-38.

Briel, H. (2013). The uses of oral history in Cyprus: ethics, memory and identity. Language and Intercultural 
Communication, 13(1), 27-43, http://dx.doi.org/10.1080/14708477.2012.748788

Broome, B. J., \& Collier, M. J. (2012). Culture, communication, and peacebuilding: A reflexive multi-dimensional contextual framework. Journal of International and Intercultural Communication, 5(4), 245-269, http://dx.doi.org/10.1080/17513057.2012.716858

Bruen, J. (2005). Educating Europeans? Language planning and policy in higher education institutions in Ireland. $\begin{array}{llll}\text { Language and } \quad \text { Intercultural } & \text { Communication, }\end{array}$ http://dx.doi.org/10.1080/14708470508668898

Buddenhagen, R. W., \& Baldwin, J. R. (2011). Performing communicative functions in development projects: An exploratory study of development practices in Tanzania. International Journal of Intercultural Relations, 36, 418-429, http://dx.doi.org/10.1016/j.ijintrel.2011.11.001

Busbridge, R., \& Winarnita, M. (2015). Dialogue and other 'men's business': Gender, conflict and multicultural politics in the diaspora. Journal of Intercultural Studies, 36(2), 202-220, http://dx.doi.org/10.1080/07256868.2015.1008434

Castles, S. (2013). The forces driving global migration. Journal of Intercultural Studies, 34(2), 122-140, http://dx.doi.org/10.1080/07256868.2013.781916

Catney, G., Finney, N., \& Twigg, L. (2011). Diversity and the complexities of ethnic integration in the UK: Guest editors' introduction. Journal of Intercultural Studies, 32(2), 107-114, http://dx.doi.org/10.1080/07256868.2011.547171

Collier, M. J. (2009). Contextual negotiation of cultural identifications and relationships: Interview discourse with Palestinian, Israeli, and Palestinian/Israeli young women in a U.S. peace-building program. Journal of International and Intercultural Communication, 2(4), 344-368, http://dx.doi.org/10.1080/17513050903177292

Collins, J. (2013). Rethinking Australian immigration and immigrant settlement policy. Journal of Intercultural Studies, 34(2), 160-177, http://dx.doi.org/10.1080/07256868.2013.781981

Coperías Aguilar, M. J. (2009). Intercultural communicative competence in the context of the European higher education area. Language and Intercultural Communication, 9(4), 242-255, http://dx.doi.org/10.1080/14708470902785642

Crosbie, V. (2014). Capabilities for intercultural dialogue. Language and Intercultural Communication, 14(1), 91-107, http://dx.doi.org/10.1080/14708477.2013.866126

Cushner, K. (2005). Conflict, negotiation, and mediation across cultures. Highlights from the fourth biennial conference of the International Academy for Intercultural Research. International Journal of Intercultural Relations, 29(6), 635-638, http://dx.doi.org/10.1016/j.jintrel.2005.07.014

Cvajner, M., \& Sciortino, G. (2010). Theorizing irregular migration: the control of spatial mobility in differentiated societies. European Journal of Social Theory, 13(3), 389-404, http://dx.doi.org/10.1177/1368431010371764

da Silva, V., \& Drawert, H. (2011). Zur linguistischen Analyse biographisch narrativer Interviews: die Innen- und Außenperspektive internationaler Studierender am Beispiel von zwei aktuellen Forschungsprojekten [On doing linguistic analyses of biographical and narrative interviews: Internal and external perspectives of international students. Shown at the example of two current research projects]. Interculture Journal, 11(16), $167-180$.

Dahinden, J., Duemmler, K., \& Moret, J. (2014). Disentangling religious, ethnic and gendered contents in boundary work: How young adults create the figure of 'the oppressed Muslim woman'. Journal of Intercultural Studies, 35(4), 329-348, http://dx.doi.org/10.1080/07256868.2014.913013

Davidheiser, M. (2005). Culture and mediation: A contemporary processual analysis from southwestern Gambia. International Journal of Intercultural Relations, 29(6), 713-738, http://dx.doi.org/10.1016/j.ijintrel.2005.07.010

Dawe, K. (2007). Arcadia calling: Cretan music and the popular imagination. Journal of Intercultural Studies, 28(2), 227-236, http://dx.doi.org/10.1080/07256860701236633

De Beukelaer, C., \& Duxbury, N. (2014). Real sustainable development requires change through culture. The Conversation. 
Dervin, F. (2014). Exploring 'new' interculturality online. Language and Intercultural Communication, 14(2), 191-206, http://dx.doi.org/10.1080/14708477.2014.896923

Downman, S. (2012). The forgotten family: Labour migration and the collapse of traditional values in Thailand's tribal communities. Journal of Intercultural Studies, 33(1), 53-68, http://dx.doi.org/10.1080/07256868.2012.633316

Dunne, C. (2013). Exploring motivations for intercultural contact among host country university students: An Irish case study. International Journal of Intercultural Relations, 37, 567-578, http://dx.doi.org/10.1016/j.ijintrel.2013.06.003

Dutta, M. J., \& Dutta, D. (2013). Multinational going cultural: A postcolonial deconstruction of cultural intelligence. Journal of International and Intercultural Communication, 6(3), 241-258, http://dx.doi.org/10.1080/17513057.2013.790989

Duxbury, N., \& Gillette, E. (2007). Culture as a key dimension of sustainability: Exploring concepts, themes, and models. Burnaby, B.C. Canada: Centre of Expertise on Culture and Communities.

Foucault, M. (1984 [1969]). L'archéologie du savoir [The archaeology of knowledge]. Paris: Gallimard.

Fraser, B. P., Brown, W. J., Wright, C., \& Kiruswa, S. L. (2011). Facilitating dialog about development through digital photography: Seeing through the eyes of Maasai women. Journal of International and Intercultural Communication, 5(1), 20-42, http://dx.doi.org/10.1080/17513057.2011.619667

Furcsa, L. (2009). Outcomes of an intercultural e-mail based university discussion project. Language and Intercultural Communication, 9(1), 24-32, http://dx.doi.org/10.1080/14708470802684481

$\mathrm{Gu}, \mathrm{Q}$. (2010). Variations in beliefs and practices: teaching English in cross-cultural contexts. Language and Intercultural Communication, 10(1), 32-53, http://dx.doi.org/10.1080/14708470903377357

Guilherme, M. (2007). English as a global language and education for cosmopolitan citizenship. Language and Intercultural Communication, 7(1), 72-90, http://dx.doi.org/10.2167/laic184.0

Gvion, L. (2014). Intertwining tradition with modernity: The case of Palestinian restaurants in Israel. Journal of Intercultural Studies, 35(4), 366-384, http://dx.doi.org/10.1080/07256868.2014.913010

Hawkes, J. (2001). The fourth pillar of sustainability: Culture's essential role in public planning. Melboune: Common Ground Publishing.

Heintel, P., \& Krainer, L. (2010). Geschichtlich-kulturelle Nachhaltigkeit [Historical cultural sustainability]. Erwägen - Wissen - Ethik [Deliberation - knowledge - ethics], 21(4), 435-446.

Henderson, J. (2011). New and not so new horizons: brief encounters between UK undergraduate native-speaker and non-native-speaker Englishes. Language and Intercultural Communication, 11(3), 270-284, http://dx.doi.org/10.1080/14708477.2011.583352

Hennecke, A. (2008). Brücken zwischen interkultureller Kommunikation und Technik [Bridging intercultural communication and technology]. Interculture Journal, 7(6), 73-94.

Herakova, L. L. (2009). Identity, communication, inclusion: The Roma and (New) Europe. Journal of International and Intercultural Communication, 279-297, http://dx.doi.org/10.1080/17513050903177318

Holliday, A. (2010). Cultural descriptions as political cultural acts: an exploration. Language and Intercultural Communication, 10(3), 259-272, http://dx.doi.org/10.1080/14708470903348572

Hoover, J. D. (2011). Dialogue: Our past, our present, our future. Journal of Intercultural Communication Research, 40(3), 203-218, http://dx.doi.org/10.1080/17475759.2011.617771

Humphrey, M. (2013). Migration, security and insecurity. Journal of Intercultural Studies, 34(2), 178-195, http://dx.doi.org/10.1080/07256868.2013.781982

Jakubowicz, A. (2011). Chinese Walls: Australian multiculturalism and the necessity for Human Rights. Journal of Intercultural Studies, 32(6), 691-706, http://dx.doi.org/10.1080/07256868.2011.618111

Johnson, J. L., \& Callahan, C. (2013). Minority cultures and social media: Magnifying Garifuna. Journal of Intercultural Communication Research, 42(4), 319-339, http://dx.doi.org/10.1080/17475759.2013.842608

Kealey, D. J., Protheroe, D. R., MacDonald, D., \& Vulpe, T. (2005). Re-examining the role of training in contributing to international project success: A literature review and an outline of a new training program. 
International Journal of Intercultural Relations, 29, 299-316, http://dx.doi.org/10.1016/j.ijintrel.2005.05.011

Kelman, H. C. (1998). Building a sustainable peace: The limits of pragmatism in the Israeli-Palestinian negotiations. Journal of Palestine Studies, 28(1), 36-50.

Kelman, H. C. (2005). Building trust among enemies: The central challenge for international conflict resolution. International Journal of Intercultural Relations, 29(6), 639-650, http://dx.doi.org/10.1016/j.ijintrel.2005.07.011

Kesten, J., Cochrane, A., Mohan, G., \& Neal, S. (2011). Multiculture and community in new city spaces. Journal of Intercultural Studies, 32(2), 133-150, http://dx.doi.org/10.1080/07256868.2011.547173

Khan, R. (2014). New communities, new attachments: Planning for diversity in Melbourne's outer-suburbs. Journal of Intercultural Studies, 35(3), 295-309, http://dx.doi.org/10.1080/07256868.2014.899953

Kriegel, K. (2010). Verlustreiche Konfliktbearbeitung in deutschen Unternehmen. Mediation als gewinnbringende Alternative? [Lossy conflict management in German companies. Conflict mediation as a gainful alternative?]. Interculture Journal, 9(11), 3-25.

Kubal, A. (2013). Migrants' relationship with law in the host country: Exploring the role of legal culture. Journal of Intercultural Studies, 34(1), 55-72, http://dx.doi.org/10.1080/07256868.2013.751905

Kuchenbrandt, D., van Dick, R., Koschate, M., Ullrich, J., \& Bornewasser, M. (2014). More than music! A longitudinal test of German-Polish music encounters. International Journal of Intercultural Relations, 40, 167-174, http://dx.doi.org/10.1016/j.ijintrel.2013.11.008

LaFever, M. (2008). Communication for public decision-making in a negative historical context: Building intercultural relationships in the British Columbia treaty process. Journal of International and Intercultural Communication, 1(2), 158-180, http://dx.doi.org/10.1080/17513050801891978

Mansouri, F., \& Pietsch, J. (2011). Local governance and the challenge of religious pluralism in liberal democracies: An Australian perspective. Journal of Intercultural Studies, 32(3), 279-292, http://dx.doi.org/10.1080/07256868.2011.565738

Marsella, A. (2005). Culture and conflict: Understanding, negotiating, and reconciling conflicting constructions of reality. International Journal of Intercultural Relations, 29(6), 651-673, http://dx.doi.org/10.1016/j.ijintrel.2005.07.012

Meadows, D. H., Meadows, D. L., Randers, J., \& Behrens III, W. W. (1972). The Limits to Growth. A Report for the Club of Rome's Project on the Predicament of Mankind. London: Earth Island.

Mendoza, S. L. (2010). Reflections on "Bridging paradigms: How not to throw out the baby of collective representation with the functionalist bathwater in critical intercultural communication". In T. K. Nakayama, \& R. T. Halualani (Eds.), The handbook of critical intercultural communication (pp. 98-111). Chichester: Wiley-Blackwell.

Mondain, N., \& Diagne, A. (2013). Discerning the reality of 'those left behind' in contemporary migration processes in Sub-Saharan Africa: Some theoretical reflections in the light of data from Senegal. Journal of Intercultural Studies, 34(5), 503-516, http://dx.doi.org/10.1080/07256868.2013.827831

Moosmüller, A., \& Schönhuth, M. (2009). Intercultural competence in German discourse. In D. K. Deardorff (Ed.), The Sage handbook of intercultural competence (pp. 209-232). Thousand Oaks/ London/ New Delhi/ Singapore: Sage.

Morris, R. (2010). The scarlett letter, vigilantism, and the politics of sadism. In T. K. Nakayama, \& R. T. Halualani (Eds.), The handbook of critical intercultural communication (pp. 472-482). Chichester: Wiley-Blackwell.

Muñoz, S.-A. (2011). Ethno-faith-burbs: Religious affiliation and residential patterns of the Indian ethnic populations of Dundee and Glasgow. Journal of Intercultural Studies, 32(2), 115-131, http://dx.doi.org/10.1080/07256868.2011.547172

Nazarkiewicz, K. (2003). Die kommunikative Vermittlung interkultureller Kompetenz in Trainings zur interkulturellen Kommunikation [The communicative mediation of intercultural competence in trainings on intercultural communication]. Interculture Journal, 2(5), 1-19.

Nijhuis, C. J. G., Voogt, J. M., \& Pieters, J. M. (2011). The cultural complexity of international collaboration: 
Conditions for sustainable curriculum development in Ghana. International Journal of Intercultural Relations, 36, 647-658, http://dx.doi.org/10.1016/j.ijintrel.2012.02.003

Ojwang, B. O. (2008). Prospects of Kiswahili as a regional language in a socioculturally heterogeneous East Africa. Journal of International and Intercultural Communication, 1(4), 327-347, http://dx.doi.org/10.1080/17513050802344670

Parodi, O., Ayestaran, I., \& Banse, G. (Eds.). (2011). Sustainable development. Relationships to culture, knowledge and ethics (Karlsruher Studien Technik und Kultur). Karlsruhe: KIT Scientific Publishing.

Pearson, J. C., Semlak, J. L., Western, K. J., \& Herakova, L. L. (2010). Answering a call for service: An exploration of family communication schemata and ethnic identity's effect on civic engagement behaviors. Journal of Intercultural Communication Research, 39(1), 49-68, http://dx.doi.org/10.1080/17475759.2010.520838

Ploner, J. (2009). Narrating regional identity in tourism - sketches from the Austrian Danube valley. Language and Intercultural Communication, 9(1), 2-14, http://dx.doi.org/10.1080/14708470802684465

Poucki, S., \& Bryan, N. (2014). Vulnerability to human trafficking among the Roma population in Serbia: The role of social exclusion and marginalization. Journal of Intercultural Studies, 35(2), 145-162, http://dx.doi.org/10.1080/07256868.2014.885417

Poynting, S., \& Mason, V. (2006). "Tolerance, freedom, justice and peace"?: Britain, Australia and Anti-Muslim racism since 11 September 2001. Journal of Intercultural Studies, 27(4), 365-391, http://dx.doi.org/10.1080/07256860600934973

Rathje, S. (2003). Holzhammer und Mimose - Interkulturelles Konfliktverhalten in der deutsch-thailändischen Zusammenarbeit [Sledge hammer and sissy: Intercultural conflict behavior in German-Thai cooperation]. Interculture Online, 2(3), Retrieved from http://www.interculture-journal.com/index.php/icj/article/view/10

Rathje, S. (2006). Zusammenhalt in der Zwischenzeit. Neue Ansätze zur Erhaltung von Unternehmenskultur in der M\&A-Planung [Social cohesion in interim periods. New approaches to sustain corporate cultures when planning an M\&A]. Interculture Journal, 5(1), 103-122

Rienties, B., \& Nolan, E.-M. (2013). Understanding friendship and learning networks of international and host students using longitudinal Social Network Analysis. International Journal of Intercultural Relations, 41, 165-180, http://dx.doi.org/10.1016/j.ijintrel.2013.12.003

Rivers, D. J. (2011). Evaluating the self and the other: Imagined intercultural contact within a 'native-speaker' dependent foreign language context. International Journal of Intercultural Relations, 35, 842-852, http://dx.doi.org/10.1016/j.ijintrel.2011.08.003

Robinson, J. (2004). Squaring the circle? Some thoughts on the idea of sustainable development. Ecological Economics, 48, 369-384, http://dx.doi.org/10.1016/j.ecolecon.2003.10.017

Salzman, M. B. (2008). Globalization, religious fundamentalism and the need for meaning. International Journal of Intercultural Relations, 32, 318-327, http://dx.doi.org/10.1016/j.jintrel.2008.04.006

Saraceni, M. (2009). Relocating English: towards a new paradigm for English in the world. Language and Intercultural Communication, 9(3), 175-186, http://dx.doi.org/10.1080/14708470902748830

Scheible, D. H. (2009). Interkulturelles Training für internationale Führungskräfte. Evaluation eines Trainingsprogramms bei einem Industrieunternehmen mit Stammsitz in Deutschland [Intercultural training for international managers. An evaluation of a training programme for an industrial corporation having its headquarters in Germany]. Interculture Journal, 8(9), 71-81.

Sekimoto, S. (2012). A multimodal approach to identity: Theorizing the self through embodiment, spatiality, and temporality. Journal of International and Intercultural Communication, 5(3), 226-243, http://dx.doi.org/10.1080/17513057.2012.689314

Singer, M. (2011). Anthropology as a sustainability science. Anthropology News(April 2011), 5/10, http://dx.doi.org/10.1111/j.1556-3502.2011.52405.x

Spitzberg, B. H., \& Changnon, G. (2009). Conceptualizing intercultural competence. In D. K. Deardorff (Ed.), The SAGE Handbook of Intercultural Competence (pp. 2-52). Thousand Oaks/ London/ New Delhi/ Singapore: Sage.

Stibbe, A. (2004). Environmental education across cultures: Beyond the discourse of shallow environmentalism. 
Language and Intercultural Communication, 4(4), 242-260, http://dx.doi.org/10.1080/14708470408668875

Stier, J. (2006). Internationalization, intercultural communication and intercultural competence. Journal of Intercultural Communication, 11, 1-12.

Stolle-McAllister, J. (2013). Intercultural processes in Kichwa governed municipalities in Northern Ecuador. Journal of Intercultural Studies, 34(1), 1-17, http://dx.doi.org/10.1080/07256868.2013.751907

Strewe, B. (2007). Qualifizierung von Kursleitenden im Rahmen der Integrationskurse des Bundesamtes für Migration und Flüchtlinge. Konzeption und Umsetzung [Qualifying trainers for integration courses to immigrants provided by the German federal office for migration and refugees. Concept and implementation]. Interculture Journal, 6(3), 107-130.

Takahashi, B., \& Meisner, M. (2011). Comparing influences on Peruvian climate change policy: Information, knowledge, and concern among political elites. Journal of Intercultural Communication Research, 40(3), 181-202, http://dx.doi.org/10.1080/17475759.2011.615854

Tamam, E. (2010). Examining Chen and Starosta's model of intercultural sensitivity in a multiracial collectivistic country. Journal of Intercultural Communication Research, 39(3), 173-183, http://dx.doi.org/10.1080/17475759.2010.534860

Tange, H. (2010). Caught in the Tower of Babel: university lecturers' experiences with internationalisation. $\begin{array}{lllll}\text { Language } \quad \text { Ind } & \text { Communication, } & \text { 10(2), }\end{array}$ http://dx.doi.org/10.1080/14708470903342138

Throsby, D. (2008). Linking cultural and ecological sustainability. The International Journal of Diversity in Organizations, Communities and Nations, 8(1), 15-20.

Timpf, S. (2003). Im Fadenkreuz. Dispositiv und Gouvernementalität der Nachhaltigkeit [In the crosshairs: The dispositive and the governmentality of sustainability]. Peripherie, 23(92), 530-451.

Tran, L. T. (2009). Making visible 'hidden' intentions and potential choices: international students in intercultural communication. Language and Intercultural Communication, 9(4), 271-284, http://dx.doi.org/10.1080/14708470902807693

Tsuda, Y. (2010). Speaking against the hegemony of English. Problems, ideologies, and solutions. In T. K. Nakayama, \& R. T. Halualani (Eds.), The handbook of critical intercultural communication (pp. 248-269). Chichester: Wiley-Blackwell.

UN Department of Economic and Social Affairs (2006). Agenda 21. Division for Sustainable Development. Retrieved from http://www.un.org/esa/sustdev/documents/agenda21/index.htm

Vachon, S. (2010). International operations and sustainable development: Should national culture matter? Sustainable Development, 18(5), 350-261, http://dx.doi.org/10.1002/sd.398

Waibel, I. (2012). Interkulturelle Online-Communities im Hochschulbereich: Konzept für ein deutsch-polnisches Hochschulnetzwerk [Intercultural online communities in the academia. Building a German-Polish university network]. Interculture Journal, 11(16), 187-196.

WCED (1987). Our Common Future. Report of the World Commission on Environment and Development. New York: United Nations.

Wei, X. (2009). On negative cultural transfer in communication between Chinese and Americans. Journal of Intercultural Communication, 21, Retrieved from: http://www.immi.se/intercultural/nr21/wei.htm

Woods, P., Poropat, A., Barker, M., Hills, R., Hibbins, R., \& Borbasi, S. (2011). Building friendship through a cross-cultural mentoring program. International Journal of Intercultural Relations, 37, 523-535, http://dx.doi.org/10.1016/j.ijintrel.2013.08.004

\section{Copyrights}

Copyright for this article is retained by the author(s), with first publication rights granted to the journal.

This is an open-access article distributed under the terms and conditions of the Creative Commons Attribution license (http://creativecommons.org/licenses/by/3.0/). 